\title{
Experimental evaluation of commercial-scale enhancement of abalone Haliotis iris populations in New Zealand
}

\author{
David R. Schiel \\ Department of Zoology, University of Canterbury, Private Bag 4800, Christchurch 1, New Zealand
}

\begin{abstract}
The viability of enhancing populations of abalone Haliotis iris by placing hatchery-raised juveniles into natural habitats was evaluated at the Chatham Islands, New Zealand. Eighty thousand abalone, from 3 to $30 \mathrm{~mm}$ (shell length) in size, were seeded into 8 sites during 1990 and 1991 and sampled for survival and growth at times ranging from 5 to 23 mo. Annual mortality rates were 27.6 to $98.8 \%$ and instantaneous mortality ranged from 0.323 to 4.440 . Mortality was greatest in sites affected by sand movement, which partially buried juvenile habitat. Desirable characteristics of sites for enhancement were identified so that the risk of mortality due to habitat shifts can be greatly reduced in the future. Average annual growth increments ranged from 13.5 to $23.8 \mathrm{~mm}$, but the lower value may be conservative because of the varying growth periods that seed were in place at the different sites. Preliminary economic analyses showed that, based on the current price of abalone, 3 individual sites should produce positive financial returns on the future harvest of abalone at the minimum legal size of $125 \mathrm{~mm}$. Although 5 sites will have negative financial returns, the overall return of the 8 sites should exceed the original investment.
\end{abstract}

\section{INTRODUCTION}

There is considerable interest in the methods and means of restoring marine populations that have been damaged or depleted in some way (Thayer 1992). To be successful, this type of work requires a considerable knowledge about the life history of target organisms and an understanding of their ecology. In particular, it is necessary to know the links between early life stages and adult stages in terms of habitat requirements, growth and survival. These links are far from clear for most species. Especially in long-lived species, the relationship between the numbers of juveniles and adults may break down under the influences of resource limitation, predation, and environmental conditions (Underwood \& Denley 1984, Connell 1985, Keough 1988, Jones 1990). These relationships have considerable importance in commercially-exploited species for which economic value is attached to management decisions. Moreover, any attempts at restoration or enhancement of fished populations must be economically viable.
One area where marine restoration may have a chance of success is in invertebrate fisheries, which are susceptible to overfishing (Harrison 1986). This is particularly true of the commercially valuable abalone fisheries, which have suffered serial depletion in many countries, including New Zealand (Shepherd et al. $1992 \mathrm{~b}$ ). The possibility of augmenting heavily exploited abalone populations to help ensure their longterm sustainability by enhancement with hatcheryraised seed has been explored in a few countries (Saito 1984, Tegner \& Butler 1989). The interest in establishing such a programme in New Zealand is more recent and has been in response to the perception that natural recruitment is irregular in many fishing sites (Sainsbury 1982a) and that the current high levels of fishing effort in the commercial and recreational fishery may not be sustainable (Schiel 1992b). Population enhancement, in conjunction with various management initiatives, was seen as a means of significantly increasing recruitment to the fishery.

Attempts at enhancing abalone populations have produced variable results (reviewed in Tegner \& Butler 
1989). In southern California (USA), it appears that few seeded juveniles of Haliotis rufescens survived to harvestable size despite many releases (Tegner \& Butler 1985, 1989). Most seeded abalone were never seen after release. Significant mortality was due to predation by crabs, lobsters and octopus, to the stressed condition of the hatchery-reared juveniles after their transport to seeding sites, and to alterations of habitat following storms. Trials in Japan with $H$. discus hannai have also had variable results but successes have been reported, with some seeded abalone eventually being captured in the commercial fishery (Saito 1984). Where recapture rates of seeded abalone were high, the size of seed at release was generally $\geq 30 \mathrm{~mm}$ (Saito 1984, Tegner \& Butler 1989).

New Zealand native abalone (or paua) Haliotis iris are relatively slow-growing, with average increments in shell length of 20 to $25 \mathrm{~mm} \mathrm{yr}^{-1}$ as juveniles (Poore 1972c). In a hatchery, the cost of raising smail abaione is considerably less than raising larger juveniles because of the feed, attention, and time required to maintain cultures of larger animals. Therefore, much greater numbers of smailer indiviuuais can be cultured for a given cost. Because it is necessary for seeding projects to be financially viable, the trade-offs between costs of seed production, the size at release, and the survival to harvestable size must be considered (Schiel 1989). In New Zealand, there is only one small hatchery capable of raising juvenile paua. Growing them to larger sizes is hampered by the lack of a cheap and abundant food. Because of the limitations on space and food, any programme seeking to use large numbers of hatchery-raised paua for enhancement of populations is constrained to using small juveniles $(<20 \mathrm{~mm})$, which can be raised in the available facility (Tong \& Moss 1992). Using seed paua of 8 to $15 \mathrm{~mm}$ in size provides a reasonable balance between costs and returns (Schiel 1992a). In small-scale experiments, the recovery of $20 \mathrm{~mm}$ paua was slightly greater than $12 \mathrm{~mm}$ paua (Schiel unpubl. data) but the cost of producing the smaller paua was considerably less.

As for many abalone species, Haliotis iris juveniles $(<70 \mathrm{~mm})$ are associated with under-boulder habitat (Poore 1972c, Sainsbury 1982a, Shepherd \& Turner 1985). The selection of appropriate habitats, therefore, was considered likely to be one of the most critical factors affecting the survival of seeded paua. Previous small-scale experiments on $H$. iris showed that mortality due to predation by fish and large invertebrates was not great, or at least was not detectable against the background of other factors (Schiel 1992a, unpubl. data). However, habitat-related factors such as shifts in sand and movement of rocks accounted for most mortality, a result also reported by Sainsbury (1982a).
Paua generally occur in water depths $<5 \mathrm{~m}$ (Poore 1972C, Sainsbury 1982a). Sites where extensive sand and rock movement occur are usually poor habitat for juveniles. Rocky reefs that provide good juvenile habitat are relatively common around the Chatham Islands, New Zealand, where there is a substantial commercial paua fishery (Schiel 1992b). This study was designed as a large-scale experiment in which growth and survival of seeded paua were assessed within a range of sites around the island. The objectives were to determine the habitat characteristics suitable to enhancement on a commercial scale and to provide information on whether seeding is an economically viable form of paua population enhancement.

\section{MATERIALS AND METHODS}

Study sites. The Chatham Islands are situated $700 \mathrm{~km}$ from mainland New Zealand at $44^{\circ} \mathrm{S}, 176^{\circ} \mathrm{W}$ on the eastern edge of the Chatham Rise (Fig. 1), a submarine ridge 250 to $500 \mathrm{~m}$ deep. The Chathams consist of 2 main islands and several rocky outcrops. They comprise a major fishery management area for Haliotis iris, with about $292 \mathrm{t}$ caught annually (Schiel 1992b). Paud of all sizes are very abundant around the islands on virtually all rocky inshore reefs (Schiel unpubl. data). This study was done on the main island, Chatham Island.

I searched extensively for good juvenile habitat, seeking sites of at least several hundred $\mathrm{m}^{2}$ with small boulders on rocky reefs. This type of large-scale juvenile habitat is patchy in occurrence around Chatham

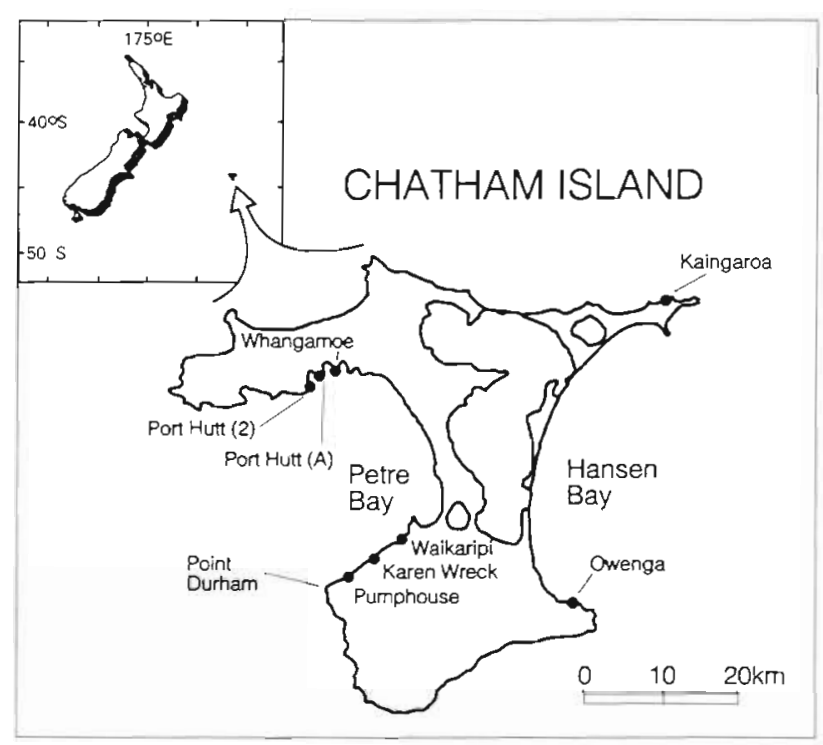

Fig. 1. Map of Chatham Island showing location of sites seeded with Haliotis inis 
Table 1. Descriptions and characteristics of enhancement sites at Chatham Island. Wind direction is that of greatest exposure at each site

\begin{tabular}{|c|c|c|}
\hline Site & Exposure & Characteristics \\
\hline Port Hutt (Alabama) & ) $\mathrm{S}-\mathrm{SW}$ & $\begin{array}{l}\text { Extensive boulder and } \\
\text { small rock }\end{array}$ \\
\hline Owenga & $N-E$ & $\begin{array}{l}\text { Some reef, smaller } \\
\text { rock, large sand patches }\end{array}$ \\
\hline Port Hutt (2) & S-SW & $\begin{array}{l}\text { Extensive reef, some } \\
\text { small rock }\end{array}$ \\
\hline Whangamoe & S-SW & $\begin{array}{l}\text { Some reef, large } \\
\text { boulders and rock }\end{array}$ \\
\hline Waikaripi & NW-SW & $\begin{array}{l}\text { Steep reef, some smaller } \\
\text { rock }\end{array}$ \\
\hline Karen Wreck & NW-SW & $\begin{array}{l}\text { Some reef, boulders and } \\
\text { smaller rock }\end{array}$ \\
\hline Pumphouse & NW-SW & $\begin{array}{l}\text { Some reef, boulders and } \\
\text { smaller rock }\end{array}$ \\
\hline Kaingaroa & $W, N-E$ & $\begin{array}{l}\text { Reef, some smaller rocks, } \\
\text { extensive sand patches }\end{array}$ \\
\hline
\end{tabular}

Island and many areas were excluded from the seeding experiment because of severe exposure, inadequate access, or inappropriate habitats. Much of the inshore habitat of Chatham Island is composed of sand, especially in the long expanses of Hansen Bay, Petre Bay, and the north coast. Other areas had difficult access (the northwest coast) or were continually exposed to severe sea conditions (the south coast). Consequently, study sites could not be spaced evenly around the island. Eight were chosen that represented a range of conditions, but all had rocky reefs with extensive juvenile habitat (Fig. 1, Table 1). It was anticipated that some sites would prove to be inappropriate for largescale seeding. In particular, Kaingaroa and Owenga were surrounded by sand, which can shift during storms.

Chatham Island is extremely exposed to wind and sea conditions. Prevailing southwesterly winds produce a swell that refracts around Point Durham. The
Port Hutt and Whangamoe sites are more protected by headlands. However, during southerly storms the full force of waves several meters in height can strike these sites. Kaingaroa and Owenga are affected by winds from north through southeast.

Hatchery methods. Eighty thousand juvenile paua (10000 per site) were required for the project, with the intention of seeding them over a 6 mo period. However, the production schedule of seed paua was not met and seeding was therefore extended over 1990-1991 (Table 2). Several batches of paua juveniles were grown during this period at the Ministry of Agriculture \& Fisheries hatchery in Wellington. Because of the geographic isolation of the Chatham Islands and the possibility of a separate genetic stock there, adult paua from the Chathams were used for spawning in the hatchery. At least 8 males and 8 females were used in each spawning to minimise the risks of loss of genetic variation (Smith \& Conroy 1992).

The techniques used to spawn adults, rear and settle larvae, and raise juvenile paua have been described elsewhere (Tong \& Moss 1992). It took 4 to 6 mo to raise paua to an average size of ca $10 \mathrm{~mm}$. Because of limitations on available rearing tanks, however, paua were settled and grown in separate batches. The first lot of 10000 was raised during 1989 and seeded in January 1990 (Table 2); 30000 were available in May 1990 and seeded at 3 sites; 30000 were grown during late 1990 and seeded in February 1991; 10000 were grown in late 1990 and seeded in May 1991.

Although the intention was to use seed paua of a narrow size range ( 8 to $12 \mathrm{~mm}$ ), this proved to be difficult to achieve for several reasons: (1) paua were raised in different tanks and during different times in the hatchery; (2) sometimes it was necessary to hold abalone for a few months before field conditions were suitable for seeding; (3) there was considerable variability in the growth of paua both within and between rearing tanks. For example, paua from 2 settlements $10 \mathrm{~d}$ apart during April 1990 and grown in 5 different tanks were significantly different in size in the hatchery in

Table 2. Haliotis ins. Summary of seeding history of abalone at Chatham Island sites

\begin{tabular}{|c|c|c|c|c|c|}
\hline Site & $\begin{array}{l}\text { Depth } \\
\text { (m) }\end{array}$ & Seeding date & Final sample & $\begin{array}{c}\text { Area } \\
\text { seeded }\left(\mathrm{m}^{2}\right)\end{array}$ & $\begin{array}{c}\text { Number } \\
\text { seeded }\end{array}$ \\
\hline Port Hutt (Alabama) & $2-3$ & $10 \mathrm{Jan} 90$ & $12 \operatorname{Dec} 91$ & 507 & 10000 \\
\hline Owenga & $1-3$ & 11 May 90 & 23 May 91 & 280 & 9900 \\
\hline Port Hutt (2) & $2-3$ & 12 May 90 & 9 Dec 91 & 150 & 9850 \\
\hline Whangamoe & $2-3$ & 13 May 90 & 12. Dec 91 & 340 & 9850 \\
\hline Waikaripi & $3-4$ & 20 Feb 91 & $11 \operatorname{Dec} 91$ & 800 & 7900 \\
\hline Karen Wreck & $1-3$ & 22 Feb 91 & 11 Dec 91 & 900 & 10018 \\
\hline Pumphouse & $1-3$ & 22 Feb 91 & 11 Dec 91 & 500 & 8523 \\
\hline Kaingaroa & $1-3$ & 27 May 91 & $10 \operatorname{Dec} 91$ & 625 & 10000 \\
\hline
\end{tabular}


February 1991 (ANOVA: $F_{4,1101}=137.46, \mathrm{p}<0.001$ ). The average sizes of paua in the 5 tanks ranged from 11.3 to $18.7 \mathrm{~mm}$. I attempted to lessen any potential effects of variable seed size by mixing all of the paua available for a seeding period before placing them into habitats

When ready for seeding, paua were removed from the rearing tanks by hand, using a stream of warm water to loosen abalone from the surface. Paua were then packed into shipping tubes with wet seaweed (Gracilaria sordida) (methods and tubes described in Tong \& Moss 1992). Up to 1000 paua were placed into each tube. The tubes were held in the hatchery overnight in a seawater tank that drained itself every $2 \mathrm{~h}$. On the morning of the flight to the Chatham Islands, tubes were packed into styrofoam cartons with sealed bags of ice for chilling. At the Chathams, they were taken to Waitangi and opened in a fish packing shed. The tubes were placed into live wells used for keeping lobsters alive before export. These wells had a large capacity flow-through water system. The time from hatchery to live wells was about $7 \mathrm{~h}$.

Most paua arrived in good condition, but there was some mortality. In one shipment where all paua were counted there was $1.5 \%$ mortality (167 dead out of 10962). In another shipment, 4 tubes that were packed at a density of 1000 paua per tube suffered $47 \%$ mortality. This high mortality was an exception and paua were afterwards packed at densities no greater than 500 per tube. A greater problem was the estimation of numbers of paua in each shipment. Paua were not individually counted into tubes by hatchery staff before shipment. Instead, 5 randomly selected groups of 500 juveniles were counted and weighed, and the mean weight was used to estimate batches of 500 for each tube. When opened at the Chatham Islands it was clear that some estimates were too high. Because of these inaccuracies, all paua were individually counted after shipment to the Chatham Islands from May 1990 onwards.

Seeding methods. The 8 study sites were sampled for paua before seeding. Forty $0.25 \mathrm{~m}^{2}$ quadrats were randomly placed in each site and all paua were counted and measured. Juvenile paua were present at most sites but they were not usually of similar sizes to those that were seeded (see 'Results'). I investigated the possibility of establishing a control site near each seeding site to serve as an unseeded comparison in the event that hatchery paua were not subsequently identifiable after seeding These unseeded sites were eventually omitted because hatchery juveniles were distinguishable from natural paua, and the unseeded sites were invariably different from the corresponding seeded ones in both habitat structure and paua sizes, thereby obviating their use as 'controls'.
For transferral to study sites, seed paua were removed from live wells, counted, and placed back into shipping tubes which were packed with sealed bags of ice into cartons. When on site, about 1000 paua at a time were put into mesh bags carried by 2 divers, who placed small groups of juveniles by hand beneath rocks throughout each seeding site. Because small paua usually cling together in clumps when transported, divers ensured that individuals were separated and attached to rocks. The process of transferring 10000 seed paua took about 4 man-hours of underwater work at each site. The target seeding density was ca 50 to $70 \mathrm{~m}^{-2}$ of juvenile habitat, although total densities were lower when the entire site was taken into account. The target density was comparable to that at which larger juveniles (>20 mm) occur in good habitat at the Chatham Islands and mainland New Zealand (Schiel unpubl. data). In most cases, paua readily attached to rocks and appeared to be in good condition.

Post-seeding surveys. Paua were left for variable times before post-seeding surveys because trips to the Chatham Islands had to be timed around periods when new seed was available and weather conditions were suitable for diving. Because of the cryptic nature of small paua, the undersides of rocks were searched during surveys. Forty randomly placed $0.25 \mathrm{~m}^{2}$ quadrats were sampled on each survey. Hatchery paua were identified and measured in situ. Searches were done in nearby areas of juvenile habitat to determine if seed paua had spread from the immediate seeding site.

Small paua were easy to identify as hatchery-reared because they had a characteristic bright green mark on the apex of the shell and they usually produced a pronounced growth lip after placement into natural habitats. These marks became more difficult to discern, however, after about $2 \mathrm{yr}$, or when paua reached more than ca $50 \mathrm{~mm}$ in length. Paua whose origin was in doubt were recorded separately and it was subsequently decided to assign $50 \%$ of these as being of hatchery origin. This percentage was arbitrarily chosen but is probably conservative in estimating numbers of hatchery paua because only paua that had hatchery-type markings were included. Paua of doubtful origin usually comprised only a few individuals.

Growth of seed paua was recorded as size frequencies through time. Proportional survival of the entire seed cohort at a site was more difficult to determine. Sampling for juveniles can be quite destructive of under-boulder habitats and it was not feasible or desirable to overturn entire seeding sites to collect all seed paua that may have been present. Subsampling presented problems in that paua are very patchy in occurrence and therefore there is a high variance in any quadrat sampling of numbers. To estimate survival, the number of seeded paua were averaged over the total 
area of a site to give a benchmark for the seeding density (see Tables $2 \& 3$ ). Sampling means through time were compared to this seeding density and the $95 \%$ confidence intervals were computed using the standard error of samples.

Economic analysis. A preliminary economic analysis was done to determine whether there is any likelihood of seeding being economically viable at the Chatham Islands. The assumptions of the model are included in the 'Results'. To estimate future numbers, the mortality rates recorded for seed paua at each site were used for the juvenile period ( $3 \mathrm{yr}$ ) and an annual mortality rate of $20 \%$ was used for the next $3 \mathrm{yr}$ (Sainsbury 1982a). The future value of the money used to purchase seed paua was used as the standard against which future profits or losses were gauged. The internal rate of return (IRR) of the final financial returns against the original investment was assessed.

\section{RESULTS}

Because sites were seeded at 4 times (Table 2), results will be discussed within each seeding episode.

\section{Site at 2 years}

A site at Port Hutt, locally called Alabama, was seeded in January 1990 and sampled 3 times during the 23 mo to December 1991. The pre-seeding survey showed that juveniles were present, with $7.5 \%$ of them being $\leq 15 \mathrm{~mm}$ in shell length (Fig. 2A). The density of all paua at the site was 10.0 ind $\mathrm{m}^{-2}(\mathrm{SD}=9.72)$.

Seed paua ranged from 3 to $13 \mathrm{~mm}$ shell length (mean $=8.6 \mathrm{~mm}, \mathrm{SE}=0.08 ;$ Fig. 2B) . There was approximately $507 \mathrm{~m}^{2}$ of habitat into which were placed 10000 paua, giving a seeding density of 19.7 ind. $\mathrm{m}^{-2}$ (Table 2). After 5 mo these grew to an average size of $17.7 \mathrm{~mm}$ ( $\mathrm{SE}=0.55$; Fig. $2 \mathrm{C}$ ). The range of sizes reflected that at seeding. However, there was considerable variation in sizes at 1 yr (Fig. 2D). Paua tend to grow rapidly during the warmer months (Poore 1972c) and it is therefore likely that paua at this site had undergone 2 periods of growth. Many paua had barely grown and some were still $\leq 20 \mathrm{~mm}$, while others were as large as $48 \mathrm{~mm}$. It is unlikely that the smaller paua were the result of natural recruitment. They had clearly dis-

\section{PORT HUTT (ALABAMA)}

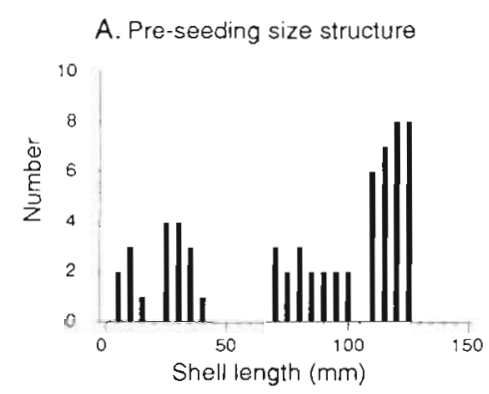

B. Initial seed sizes (10 Jan 90)

C. At five months (5 May 90 )
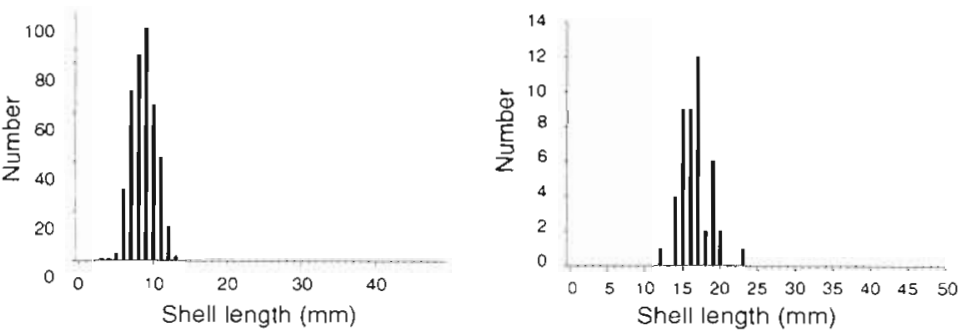

D. At one year (23 Feb 91)

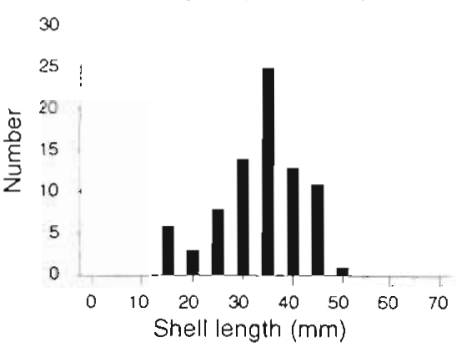

E. At two years (12 Dec 91)

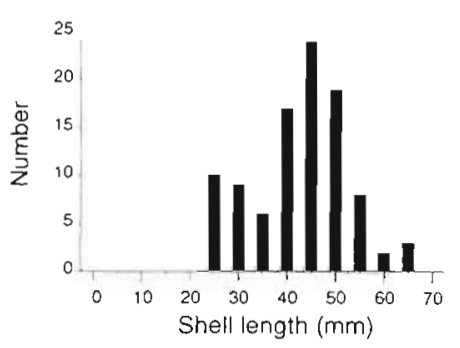

G. Survival
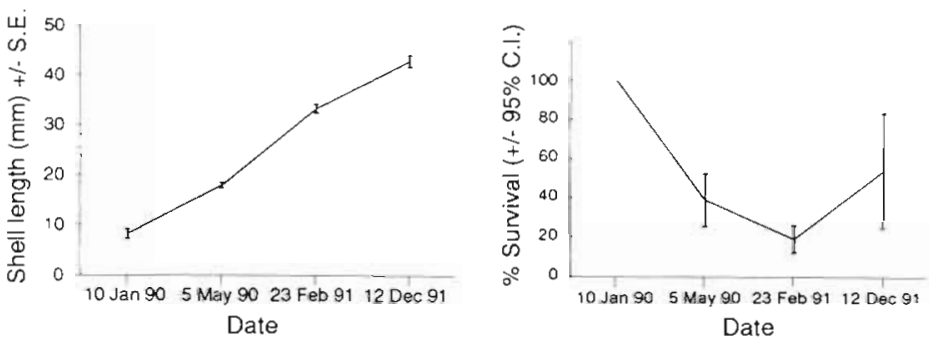

Fig. 2. Haliotis iris. Size-frequencies of abalone at Port Hutt (Alabama) (A) prior to seeding and ( $B$ to $E$ ) during the seeding experiment. ( $F$ ) Average shell length ( $\pm 1 \mathrm{SE}$ ) of seeded paua through time. (G) Percentage survival of the original cohort ( $\pm 95 \%$ confidence interval) through time

cernible green marks on the shell which are characteristic of seed paua. Furthermore, there was no evidence of recent recruits during the May 1990 sampling period.

By December 1991, seed paua ranged in size from 23 to $63 \mathrm{~mm}$ (Fig. 2E). There was almost a bimodal distribution in sizes, with peaks at ca 27 and $45 \mathrm{~mm}$. Many of the seed paua were clearly growing at a slow rate. Overall, seed paua grew from an average of $8.6 \mathrm{~mm}$ to $42.8 \mathrm{~mm}$ in $23 \mathrm{mo}$ (Fig. 2F). 
Estimates of percentage survival showed apparently anomalous results (Fig. 2G). Approximately 39\% $( \pm 13.7 \%)$ of the original 10000 seed paua survived by May 1990 , ca $19 \%( \pm 6.9 \%)$ at $1 \mathrm{yr}$, and then an average of $54 \%( \pm 29.1 \%$ ) at $23 \mathrm{mo}$. This apparent drop and rise in survival was probably the result of the non-destructive sampling procedure. Because paua become less cryptic and move into more accessible parts of the habitat as they grow, they are more likely to be encountered as they get larger. Many of the larger rocks in seeding sites were situated over smaller rocks and stones with many interstices that may conceal small paua. Larger juveniles tend to move onto the undersides of larger rocks and therefore can be seen more easily. The doubtful origin of some paua $>50 \mathrm{~mm}$ could also have contributed to the higher survival estimate on the final sampling date. This effect should be slight, however, because only $9 \%$ of the recovered paua were of doubtful origin.

\section{OWENGA}

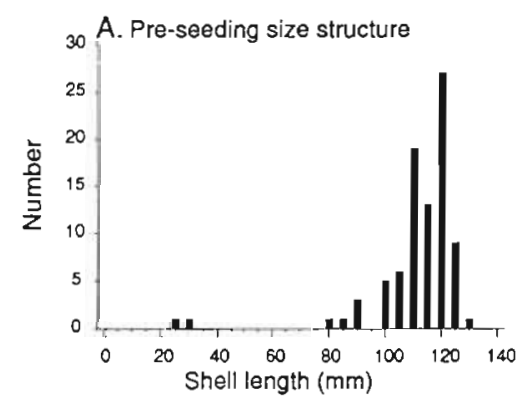

B. Initial seed sizes (11 May 90)
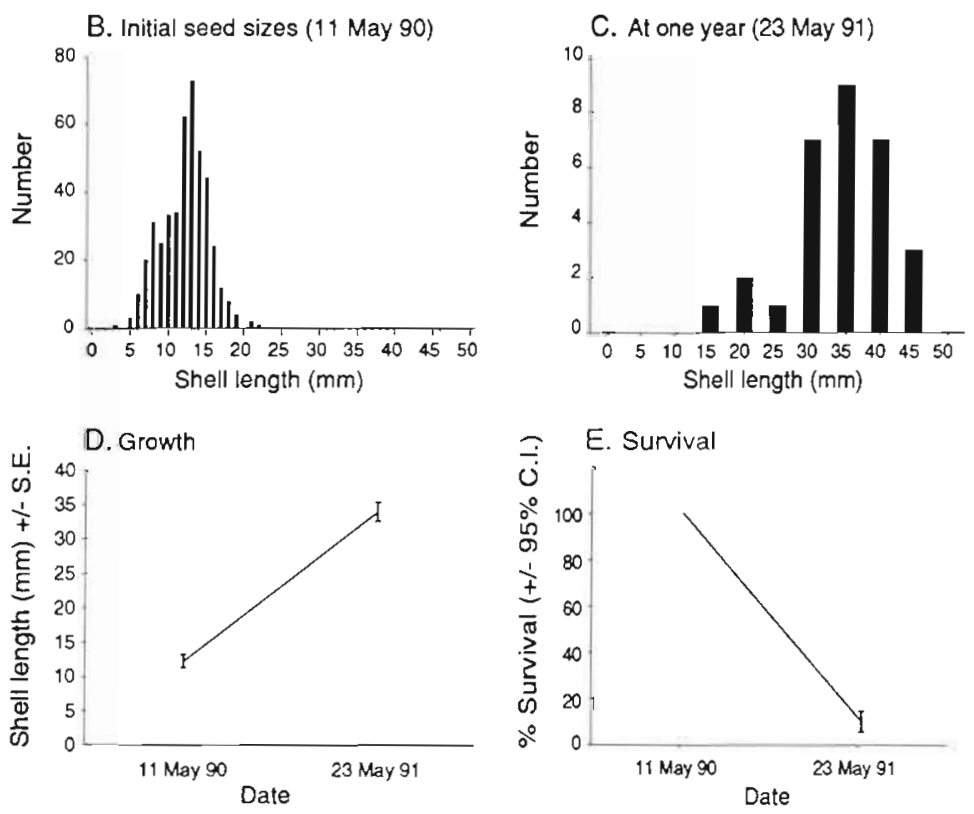

Fig. 3. Haliotis ins. Size-frequencies of abalone at Owenga (A) prior to seeding and $(B, C)$ during the seeding experiment. (D) Average shell length $( \pm 1 \mathrm{SE}$ ) of seeded paua through time. (E) Percentage survival of the original cohort ( $\pm 95 \%$ confidence interval) through time
Paua were patchy in occurrence on the final sampling date and there was a large confidence interval for the survival estimate. Nevertheless, survival was unlikely to be lower than $25 \%$ (the lower confidence interval, CI) after almost 2 yr.

\section{Sites at 1.5 years}

Three sites were seeded during May 1990 (Table 2), two of which could be sampled only once, 19 mo later in December 1991. The Owenga site is on the eastern side of Chatham Island where there is predominantly sand habitat. This site has low-lying rocks and boulders interspersed around a sandy lagoon. An outer rocky reef protects this site from the full force of easterly storms. The pre-seeding survey showed that there were some juvenile paua and many smaller adults in the area (Fig. 3A), with an overall mean of 3.4 ind. $\mathrm{m}^{-2}$ $(\mathrm{SD}=5.52)$. The habital area available to juvenile paua was ca $280 \mathrm{~m}^{2}$ (Table 2) into which 9900 paua were placed, giving a seeding density of 35.4 ind. $\mathrm{m}^{-2}$.

The seed paua ranged in size from 3 to $22 \mathrm{~mm}$ with a mean of $12.2 \mathrm{~mm}$ ( $\mathrm{SE}=0.95$; Fig. 3B). The bimodal nature of the size frequencies was due to the paua being grown in different tanks for different periods of time (see 'Methods'). They were sampled almost exactly 1 yr later in May 1991. By then their sizes ranged from 17 to $44 \mathrm{~mm}$ (Fig. 3C). The average shell length was $34 \mathrm{~mm}$ ( $\mathrm{SE}=1.36$; Fig. 3D). This was similar to the sizes attained after $1 \mathrm{yr}$ at the Port Hutt (Alabama) site, although the average initial size was larger.

Survival after 1 yr was estimated to be $9.9 \%$ ( \pm 4.44 ; Fig. 3E). There had clearly been some sand movement at this site and many of the low-lying rocks had become compacted into the substratum, rendering them no longer suitable as juvenile habitat.

The second site at Port Hutt had ca $150 \mathrm{~m}^{2}$ of juvenile habitat. It was seeded with 9850 paua, giving an overall seeding density of 65.7 ind. $\mathrm{m}^{-2}$ (Table 2). The pre-seeding size structure showed that some juvenile paua were naturally present at this site, with $5 \%$ of these $\leq 20 \mathrm{~mm}$ in length (Fig. 4A). The overall pre-seeding density of paua was 2.7 ind. $\mathrm{m}^{-2}(\mathrm{SD}=5.24)$.

The sizes of seed ranged from 5 to $22 \mathrm{~mm}$, with an average shell length of $12.2 \mathrm{~mm}$ (SE = 0.95 ; Fig. 4B), similar to the distribution of seed sizes at Owenga. There was only 1 postseeding survey, 19 mo later in December 1991 (Fig. 4C). Sizes then ranged from 21 to $53 \mathrm{~mm}$. 
The bimodal nature of sizes was still evident. Paua were on average $34.1 \mathrm{~mm}$ in shell length ( $\mathrm{SE}=1.24$; Fig. $4 \mathrm{D})$, the same size as at the Owenga site after $1 \mathrm{yr}$

Survival at Port Hutt (2) appeared to be poor (mean $=7.6 \%, \pm 3.78 ;$ Fig. $4 \mathrm{E}$ ). The juvenile habitat at this site, however, was very complex. It was surrounded by large boulders and reef, and was beneath a canopy of fucalean algae. Furthermore, it was contiguous with other patches of juvenile habitat and it is probable that seed paua migrated from the immediate site. Some seed paua were found up to $50 \mathrm{~m}$ from the seeding position.

Whangamoe was the third site seeded during May 1990. It had a juvenile habitat area of ca $340 \mathrm{~m}^{2}$ into which 9850 paua were seeded (average density $=29$ ind. $\mathrm{m}^{-2}$; Table 2). The pre-seeding survey showed an overall density of 3.1 paua ind. $\mathrm{m}^{-2}(\mathrm{SD}=$ 4.56), with few juveniles present (Fig. 5A). Seed size ranged from 5 to $22 \mathrm{~mm}$ (mean = 11.8, $\mathrm{SE}=0.90$; Fig. 5B), similar to the other 2 sites seeded in May 1990. A survey 1 yr later showed an average size of $36.6 \mathrm{~mm}$ ( $\mathrm{SE}=$ 0.63 ), with paua ranging from 20 to $48 \mathrm{~mm}$ in shell length (Fig. 5C). Sizes were more variable at 19 mo (Fig. 5D) with paua ranging from 22 to $64 \mathrm{~mm}$ in size. Most growth occurred during the first $12 \mathrm{mo}$, with only a small change in average size during the winter and spring of the final 7 mo (Fig. 5E).

Survival at 1 yr was estimated to be $18.2 \%$ $( \pm 6.92)$ and at 19 mo was $24.2 \%$ ( \pm 9.18) (Fig. 5F). Once again, where more than 1 post-seeding sample was obtained, the greatest decline in recovery occurred between seeding and the first subsequent survey.

\section{Sites at 10 months}

Three sites were seeded in February 1991 and checked again in December 1991 (Table 2). All of these sites were along the coast northeast of Point Durham.

Waikaripi had an initial density of 6.8 paua $\mathrm{m}^{-2}$ (SD $=3.64)$. A few juveniles were present, with $6.7 \%$ of them $\leq 30 \mathrm{~mm}$ in length (Fig. 6A). There was a juvenile habitat area of ca $800 \mathrm{~m}^{2}$ into which 7900 paua were placed, giving an overall seeding density of 9.9 ind. $\mathrm{m}^{-2}$. There was considerable variation in the sizes of seed, ranging from 6 to $31 \mathrm{~mm}$ (Fig. 6B). This variation was maintained as paua grew during the following $10 \mathrm{mo}$, when paua ranged from 18 to $49 \mathrm{~mm}$ in size

\section{PORT HUTT (2)}
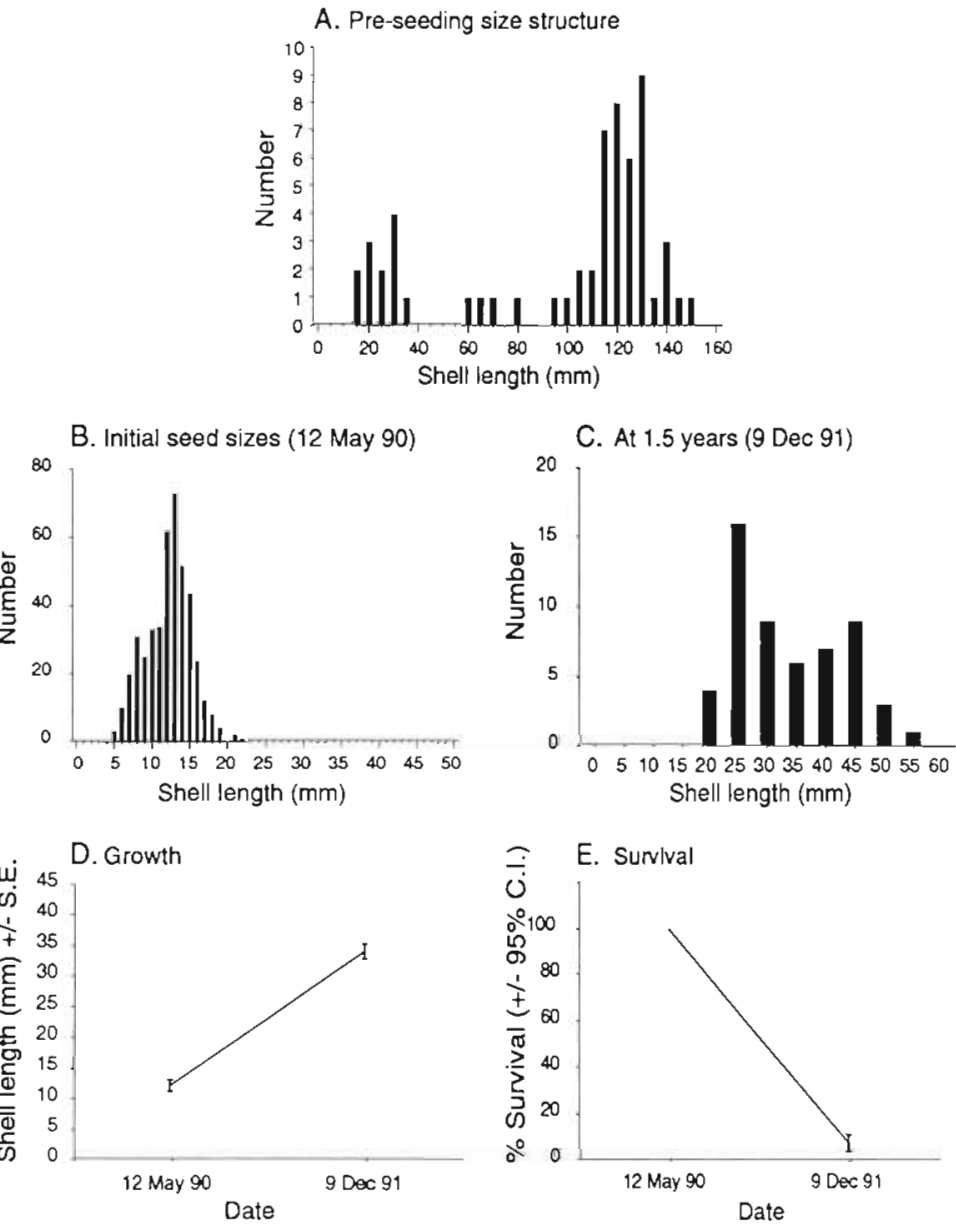

Fig. 4. Haliotis iris. Size-frequencies of abalone at Port Hutt (2) (A) prior to seeding and $(B, C)$ during the seeding experiment. (D) Average shell length $( \pm 1 \mathrm{SE}$ ) of seeded paua through time. (E) Percentage survival of the original cohort $( \pm 95 \%$ confidence interval) through time

(Fig. 6C). The average size of seed was $15.5 \mathrm{~mm}(\mathrm{SE}=$ $0.28)$, which grew to an average of $27.0 \mathrm{~mm}(\mathrm{SE}=2.10)$ 10 mo later (Fig. 6D). Percentage survival was estimated to be $19.2 \%$ ( \pm 10.35 ) by December 1991 (Fig. 6E).

The Karen Wreck site had an initial density of 14.3 paua $\mathrm{m}^{-2}(\mathrm{SD}=12.29)$. These were mostly adult paua but $6.5 \%$ of them were $\leq 30 \mathrm{~mm}$ in size (Fig. $7 \mathrm{~A}$ ). The habitat area was ca $900 \mathrm{~m}^{2}$, into which were placed 10018 hatchery paua, yielding a seeding density of 11.1 ind. $\mathrm{m}^{-2}$. Again, there was a large variation in the sizes of seed, which ranged from 7 to $29 \mathrm{~mm}$ (Fig. $7 \mathrm{~B}$ ). The post-seeding survey in December 1991 showed a size structure similar to Waikaripi, with sizes ranging from 18 to $43 \mathrm{~mm}$ (Fig. 7C). The initial size of seed averaged $14.8 \mathrm{~mm}$ ( $\mathrm{SE}=0.56)$, which grew to an average of $25.6 \mathrm{~mm}(\mathrm{SE}=0.88) 10 \mathrm{mo}$ later (Fig. 7D). 
Survival at this site was good after $10 \mathrm{mo}$. The estimated survival was $46.7 \%$, although the confidence interval was large ( \pm 20.09 ; Fig. 7E).

The Pumphouse site was the last place seeded during February 1991. It had an initial density of 5.0 paua $\mathrm{m}^{-2}(\mathrm{SD}=6.04)$. Many juvenile paua naturally occurred in this site, with almost $50 \%$ of them being $\leq 30 \mathrm{~mm}$ in size (Fig. 8A). The site had a juvenile habitat area of ca $500 \mathrm{~m}^{2}$ into which were seeded 8523 paua (seeding density $=17$ per $\mathrm{m}^{2}$ ). The initial seed size had a wide variation, ranging from 9 to $31 \mathrm{~mm}$, which was similar to that at the other 2 sites (Fig. 8B). These grew to between 19 and $53 \mathrm{~mm}$ by December 1991 (Fig. 8C). The average size of seed paua in February 1991 was 17.1 (SE = 0.40), which grew to an average size of $31.3 \mathrm{~mm}$ ( $\mathrm{SE}=1.47$ ) by December (Fig. 8D). Survival was estimated to be $29.2 \%( \pm 10.98) 10$ mo after seeding (Fig. 8E)

\section{WHANGAMOE}
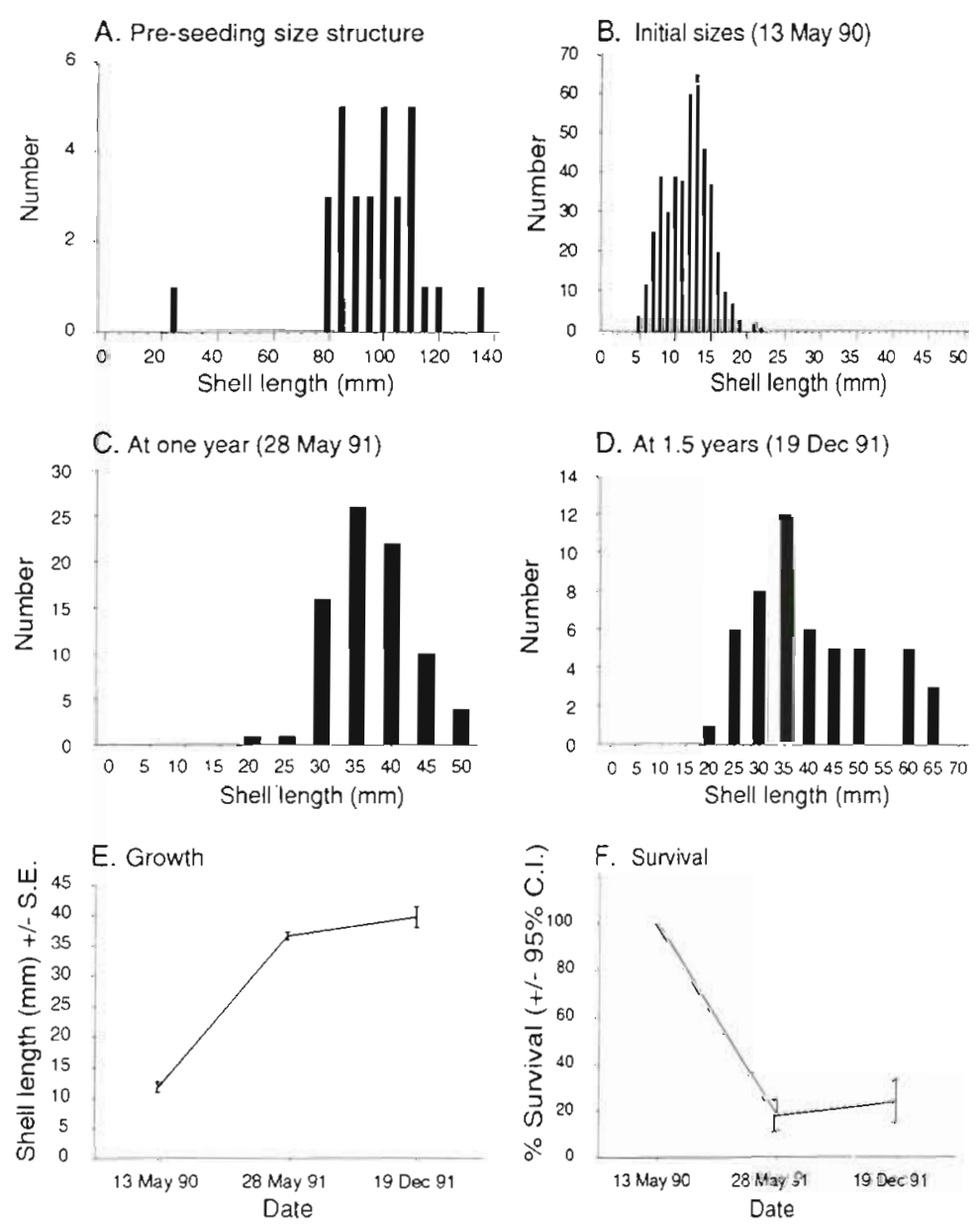

Fig. 5. Haliotis iris. Size-frequencies of abalone at Whangamoe (A) pror to seeding and ( $B$ to $D$ ) during the seeding experiment. (E) Average shell length $( \pm 1 \mathrm{SE}$ ) of seeded paua through time. $(F)$ Percentage survival of the original cohort ( $\pm 95^{\circ}$ confidence interval) through time

\section{Site at 7 months}

The last lot of 10000 paua were seeded at Kaingaroa during May 1991. The juvenile habitat area was estimated to be $625 \mathrm{~m}^{2}$, yielding an overall seeding density of 16 ind. $\mathrm{m}^{-2}$ (Table 2). The pre-seeding survey showed an initial density of 1.2 paua $\mathrm{m}^{-2}(\mathrm{SD}=3.76)$. Few juveniles were present and none were in the smaller size categories (Fig. 9A). The seed size ranged from 6 to $23 \mathrm{~mm}$, with most paua at 9 to $12 \mathrm{~mm}$ (Fig. 9B). Seven months later these ranged in size from 16 to $26 \mathrm{~mm}$ (Fig. 9C). The average initial seed size in May was $11.6 \mathrm{~mm}$ (SE $=1.16$ ). Paua grew to an average of $20.7 \mathrm{~mm}$ ( $\mathrm{SE}=1.00$ ) by December (Fig. 9D). Survival at this site was poor (Fig. 9E). There was considerable sand movement over the site by December and many of the rocks in the seeding area had been covered or partially buried by sand. Survival was estimated to be $7.5 \%( \pm 7.35)$. Because of the abundance and movement of sand around this site, it seems unlikely that many of the seed paua will survive.

\section{Overall patterns}

Comparisons of survival and growth among seeding sites can be made only tentatively because of the different ranges of seeding sizes, the varying times of seeding, and the varying periods between seeding and the final survey. The annual mortality rate and the annual instantaneous rate of mortality were calculated for each site (Table 3). Annual mortality ranged from 27.6 to $98.8 \%$ and instantaneous mortality ranged from 0.323 to 4.440 . The major noteworthy feature is that the site where paua had been in place for the longest time, Port Hutt (Alabama), also had the lowest mortality rates. This translates to an average annual survival of $72 \%$ over the first $2 \mathrm{yr}$. The greatest mortality may occur in the first few months after seeding (cf. Fig. 2G), although an accurate assessment of mortality during the first year can be confounded by the cryptic nature of small paua. It is possible that future sampling will show greater survival at several sites, particularly Port Hutt (2), Waikaripi, Karen Wreck and Pumphouse.

Annualized average growth rates varied between 13.5 to $23.8 \mathrm{~mm} \mathrm{yr}^{-1}$ (Table 3). These may be biased because the warmer months, when growth rates are greatest, are not equally represented among the sites. 
For example, growth rates appeared to be greatest at 3 [Port Hutt (Alabama), Owenga, Whangamoe] of the 4 sites in which average growth increments could be calculated for a 12 mo period, rather than having to extrapolate growth to cover a year (as at Waikaripi, Karen Wreck, Pumphouse and Kaingaroa). At all sites, growth estimates could have been affected by differential mortality of the smallest seed paua.

Relationships among growth, mortality, and density were examined. There were no significant (ns) correlations between annual mortality and annual average growth increments ( $r_{8}=-0.472$, ns), between growth increments and density (growth vs initial density: $r_{8}=0.018$, $n s ;$ growth vs final density: $r_{8}=0.602$, ns), and between mortality and initial density $\left(r_{8}=0.130, n s\right)$. There was also no correlation between initial densities at seeding and the densities on the final sampling date in December $1991\left(\mathrm{r}_{8}=0.108, \mathrm{~ns}\right)$.

\section{Economic projections}

An analysis of the economics of enhancement at the Chatham Islands, based on the preliminary results of the experimental seeding (Table 4), must be treated as tentative because of the short time that paua were in place and the variable times for which mortality estimates were obtained at the different sites.

The value of $M$, instantaneous mortality, recorded at each site was used to assess potential survival for the first $3 \mathrm{yr}$ after seeding (Table 4). From Years 4 to $6, M=0.2$ was used, a value considered a reasonable and conservative estimate by Sainsbury (1982a) and others (Schiel \& Breen 1991). The meat weight was based on average figures from the fishery (Schiel unpubl. data). The ini-

\section{WAIKARIPI}
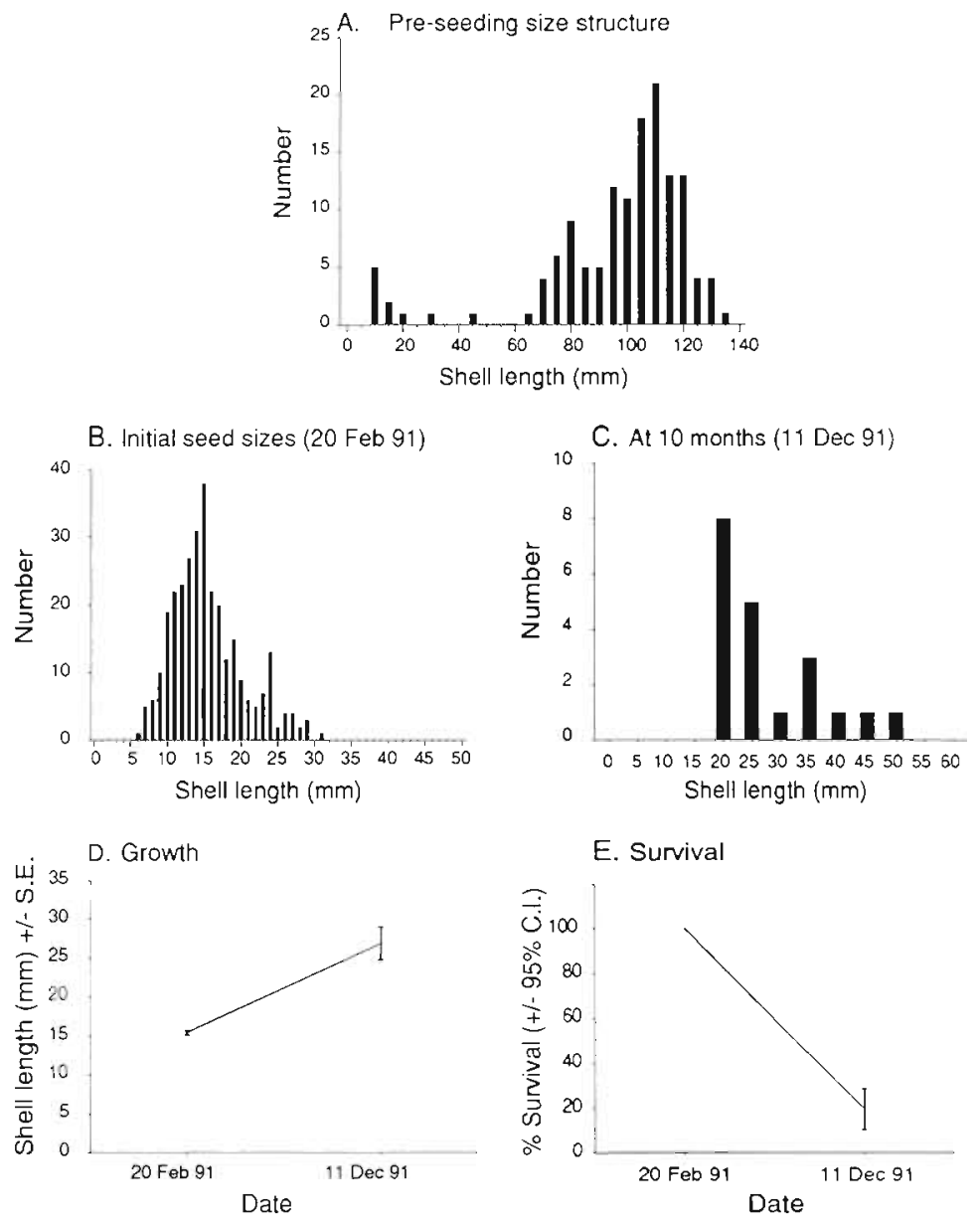

E. Survival

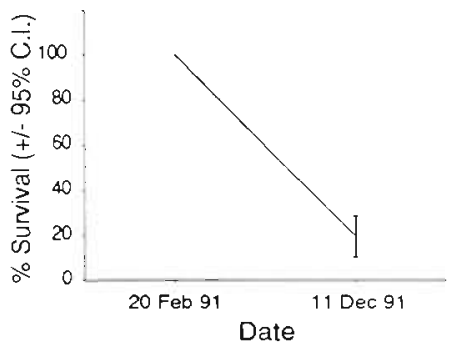

Fig. 6. Haliotis iris. Size-frequencies of abalone at Waikaripi (A) prior to seeding and $(B, C)$ during the seeding experiment. (D) Average shell length $( \pm 1 \mathrm{SE}$ ) of seeded paua through time. (E) Percentage survival of the original cohort ( $\pm 95 \%$ confidence interval) through time

tial investment was based on the cost of seed from the hatchery for each site, calculated at its future value of $5 \% \mathrm{yr}^{-1}$ for the estimated 6 to $7 \mathrm{yr}$ until paua are harvested. The internal rate of return (IRR) is the percent-

Table 3. Haliotis iris. Summary of enhancement results of abalone at Chatham Island sites. A: annual mortality rate; $M$ : instantaneous mortality

\begin{tabular}{|lccccccc|}
\hline Site & $\begin{array}{c}\text { Seeding } \\
\text { density }\left(\mathrm{m}^{-2}\right)\end{array}$ & $\begin{array}{c}\text { Final mean } \\
\text { density (SE) }\end{array}$ & $\begin{array}{c}\text { \% Survival } \\
( \pm \mathrm{CI})\end{array}$ & $\begin{array}{c}\text { Time at } \\
\text { liberty (mo) }\end{array}$ & $A$ & $\begin{array}{c}\text { Average annual } \\
\text { increment (mm) }\end{array}$ \\
\hline Port Hutt (Alabama) & 19.7 & $10.6(2.90)$ & $53.8(29.14)$ & 23 & 0.276 & 0.323 & 22.6 \\
Owenga & 35.4 & $3.5(0.80)$ & $9.9(4.44)$ & 12 & 0.901 & 2.309 & 21.0 \\
Port Hutt (2) & 65.7 & $5.0(1.24)$ & $7.6(3.78)$ & 19 & 0.803 & 1.627 & 14.0 \\
Whangamoe & 29.0 & $7.0(1.36)$ & $24.2(9.18)$ & 19 & 0.592 & 0.897 & 23.8 \\
Waikaripi & 9.9 & $1.9(0.52)$ & $19.4(10.35)$ & 10 & 0.860 & 1.965 & 14.2 \\
Karen Wreck & 11.1 & $5.2(1.12)$ & $46.7(20.09)$ & 10 & 0.599 & 0.913 & 13.5 \\
Pumphouse & 17.0 & $5.0(0.96)$ & $29.1(10.98)$ & 10 & 0.773 & 1.481 & 18.3 \\
Kaingaroa & 16.0 & $1.2(0.60)$ & $7.5(7.35)$ & 7 & 0.988 & 4.440 & 15.9 \\
\hline
\end{tabular}


Table 4. Haliotis iris. Economic projections for the financial returns of abalone seeded at 8 sites at Chatham Island. Projections calculated for each site as well as all 8 sites combined. $M$ : instantaneous mortality from Table 3; IRR = internal rate of return (which needs to be $5 \%$ to break even). Assumptions were: (1) paua will take 6 yr to reach the minimum legal size of $125 \mathrm{~mm}$; (2) survival for the first $3 \mathrm{yr}$ (the juvenile period) is the figure recorded at each site during the experiment, then $80 \%$ afterwards (Sainsbury 1982a); (3) whole weight is $250 \mathrm{~g} \mathrm{paua}^{-1}$; (4) meat recovery is $42 \%$ of whole weight; (5) shell recovery is $30 \%$ of whole weight; $(6)$ the $\$$ return is $N Z \$ 75 \mathrm{~kg}^{-1}$ for meat and $N Z \$ 5 \mathrm{~kg}^{-1}$ for shell; (7) the original value of the seed was calculated as $\$ 0.20 \times$ number seeded at each site, the future value of this money was calculated at $5 \% \mathrm{yr}^{-1}$

\begin{tabular}{|lrrrrrrrrr}
\hline Site & $M$ & $\begin{array}{c}\text { No. } \\
\text { of paua }\end{array}$ & $\begin{array}{c}\text { Meat } \\
\text { weight } \\
(\mathrm{kg})\end{array}$ & $\begin{array}{c}\text { Meat } \\
\text { return }\end{array}$ & $\begin{array}{c}\text { Shell } \\
\text { weight } \\
(\mathrm{kg})\end{array}$ & $\begin{array}{c}\text { Shell } \\
\text { return }\end{array}$ & $\begin{array}{c}\text { Total } \\
\text { return }\end{array}$ & $\begin{array}{c}\text { Future } \\
\text { value of } \\
\text { investment }\end{array}$ & $\begin{array}{c}\text { Profit/ } \\
\text { loss }\end{array}$ \\
IRR (\%) \\
Port Hutt (Alabama)
\end{tabular}

age annual gain of future profits from the money invested at each site.

Only the 3 sites with relatively high survival rates showed positive financial returns. Port Hutt (Alabama) showed the greatest potential returns and a $43.7 \%$ IRR. Whangamoe showed an IRR of $14.4 \%$ and the Karen Wreck site had an IRR of $9.3 \%$. The other 5 sites had negative returns. If the data for all 8 sites are combined (Table 4) there is an overall positive financial return of the value of paua over the future value of the invested money, and an IRR of $9.6 \%$.

\section{DISCUSSION}

The major feature to emerge from this enhancement study was the considerable variation in survival from site to site. Mortality ranged from almost $100 \%$ after less than 1 yr to as low as ca $50 \%$ after almost 2 yr. The major identifiable source of mortality was the movement of sand and the complete or partial burial of juvenile habitat within sites. The long stretches of sand on both the east and west coasts of Chatham Island render the sites near them vulnerable to this source of mortality. Further evidence for the impact of sand on habitats was seen at a site south of the Owenga seeding site. This site was surveyed in January 1990 as a potential seeding area. It had hundreds of $\mathrm{m}^{2}$ of juvenile habitat and large numbers of juvenile paua. By May 1990 the site had been almost completely buried in sand, and few juvenile paua were present. This source of mortality is consistent with what was seen in finer-scale experiments within sites, where shifts in rock, gravel, and sand affected the survival of juvenile paua (Sainsbury 1982a, Schiel 1992a).

It is not known to what degree movement of seed paua within and away from seeding sites affected estimates of survival. Predominantly rocky sites such as those at Port Hutt, Whangamoe, and along the Durham coast had a large amount of adjacent habitat suitable for juvenile paua. There is some evidence that juvenile paua can move hundreds of meters over a period of a few months (Pirker 1992) and other studies have shown that abalone can move considerable distances (Newman 1966, Poore 1972b, Shepherd 1986), so it is likely that movement away from sites has occurred.

The 2 sites seeded early in the study and monitored more than once showed that the lowest percentage recovery occurred at the first sampling. This may be the result of high mortality in the mo immediately following seeding, but may also reflect the difficulty in locating small paua in their cryptic habitat. Mortality rates were low after 1 yr. At one site, Port Hutt (Alabama), it appeared that survival was greater at 2 yr than at 1 yr. This may be the result of juveniles emerging from the very heterogeneous rocky bottom and becoming less cryptic as they get larger. An earlier experiment also showed greater recovery after the first year (Schiel unpubl. data). In this experiment, 2100 individually marked paua were seeded, of which $18.7 \%$ were re- 
captured after 1 yr and $24.3 \%$ after 3 yr. It will require further monitoring to determine whether the estimates of survival at the other sites at Chatham Island follow a similar trend. The large variance associated with later estimates of survival indicates the characteristically aggregative behaviour of larger juveniles.

Although most paua appeared to be healthy and active when they were seeded, it is likely that there was some mortality associated with the seeding process and the initial period when paua became established in natural habitats. In small-scale experiments, hatchery paua survival was ca $25 \%$ lower than that of natural paua after $5 \mathrm{wk}$ (Schiel 1992a). Laboratory-based experiments on Haliotis rufescens in California showed similar results, with hatchery-raised juvenile abalone being initially more susceptible to predation and showing different movement patterns compared to natural juveniles (Schiel \& Welden 1987). These differences decreased after several days. Some data exist on the survival rates of small hatchery-raised abalone transplanted to natural habitats, so comparisons can be made to this enhancement study. Tegner \& Butler (1985) recorded $M$ values of 0.4 to 0.5 for seeded $H$. rufescens in California (see also Shepherd \& Breen 1992). The seed size, however, ranged from 45 to $71 \mathrm{~mm}$, considerably larger than that used at Chatham Island. Saito (1984) recorded annual survival rates ranging from 6 to $20 \%$ (M: 1.6 to 2.8 ) for $H$. discus hannai of 16 to $24 \mathrm{~mm}$ seeded onto natural reefs. The best annual survival rate of $30 \%$ was obtained with seed of 22 to $38 \mathrm{~mm}$. In another study with $H$. discus hannai of 10 to $20 \mathrm{~mm}$ seed size, the $M$ values ranged from 0.6 to 0.7 (Saito 1979, quoted in Shepherd \& Breen 1992). Some of the $M$ values recorded at Chatham Island fell within the ranges of these other studies. However, there were differences in how survival rates were estimated. Some studies apparently used recapture rates of seed abalone (Saito 1984), while others estimated survival using a combination of recapture of live abalone, counts of shells from dead abalone collected from seeding sites, and assumptions about the movement and survival of unseen abalone (Tegner \& Butler 1985, 1989). Because of the patchy and cryptic nature of small abalone, it is always difficult to estimate survival (Breen 1992, Shepherd \& Breen 1992).

Estimated instantaneous rates of natural mortality for wild abalone are available from a few studies. Shepherd (1987) found $M$ values of 3.5 to 4.6 for Haliotis laevigata aged 0 to 6 mo and of 0.2 to 1.1 for those aged 6 mo to 2.5 yr (quoted in Shepherd \& Breen 1992). This study showed decreasing mortality with increasing age. McShane (1991) found that survival of recruits (<30 $\mathrm{mm}$ ) of $H$. rubra in Victoria, Australia, was as low as $0.3 \%$ after 5 mo $(M=$ 5.8), but that there was considerable variation among populations and among different years in the same population. His data also indicated that survival may be density-dependent. In my seeding trials, no densitydependence was detected. The only natural mortality data available for $H$. iris showed that $M$ values fell into the range of 0.02 to 0.25 for abalone $>2 \mathrm{yr}$ old (Sainsbury 1982a). The results and implications from these studies are that initial mortality rates are quite high for juvenile abalone of all species and that $M$ decreases as abalone grow to larger sizes.

\section{KAREN WRECK SITE}
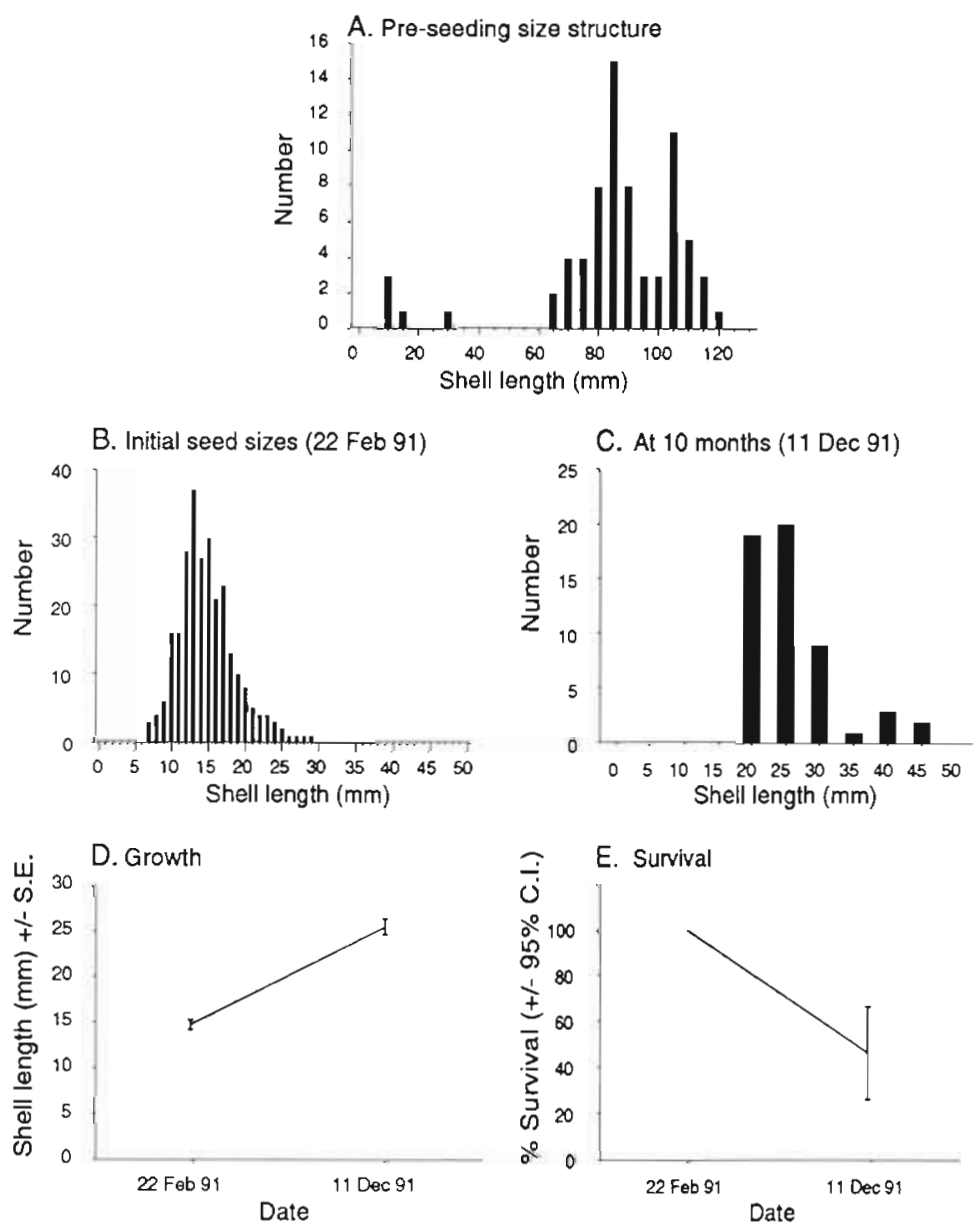

Fig. 7. Haliotis iris. Size-frequencies of abalone at Karen Wreck site (A) prior to seeding and $(B, C)$ during the seeding experiment. (D) Average shell length $( \pm 1 \mathrm{SE})$ of seeded paua through time. (E) Percentage survival of the original cohort $( \pm 95 \%$ confidence interval) through time 


\section{PUMPHOUSE SITE}

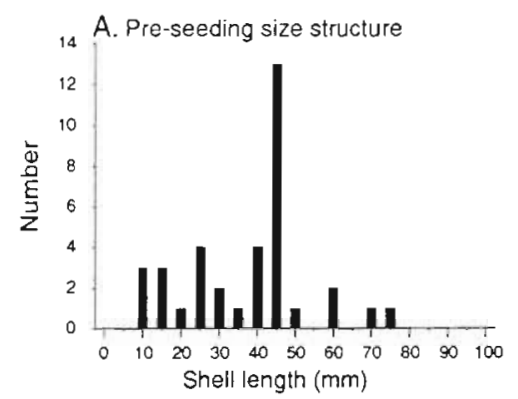

B. Initial seed sizes (22 Feb 91)
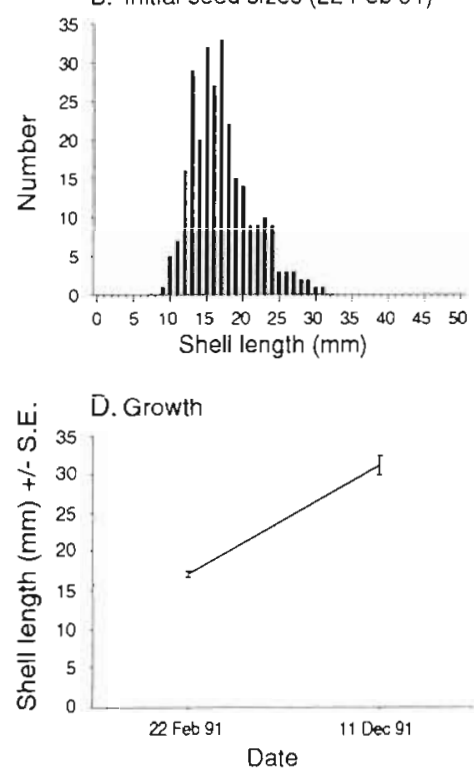

dictability in the size of recaptured paua, it may be necessary to minimize the range of sizes of seed paua by rigorous size-grading in the hatchery.

The problems of assessing growth and mortality highlight the cooperation that is necessary between the hatchery and field programs in enhancement work. Having seed abalone of a narrow size-range helps both in assessing growth and in identifying seed in future field surveys. Good hatchery techniques are essential to successful seeding of abalone. Abalone that have been stressed in the hatchery or are obviously stressed upon placing into natural habitats have little chance of survival (Tegner \& Butler 1985, 1989, Schiel 1992a). The greatest stresses to abalone occur in packing and transport (Ino 1966, Whang \& Chung 1977). It was helpful to place paua into fast-flowing seawater as soon as possible after transport. This removed faecal material from transport tubes and allowed paua to move around in their tubes and feed on the algae inside. Little mortality occurred after paua were acclimatised in this fashion. Further hatchery cooperation is needed to mark or cohort-tag abalone in the large numbers necessary for commercial seeding. The ability to identify paua as being of hatchery origin is essential in assessing the success of enhancement programmes. One effective means of tagging paua indelibly is to feed them sequentially in the hatchery on different foods. By switching the algae from Gracilaria sordida to Macrocystis pyrifera every few weeks, for example, alternating bands of dark and bright green shell can be laid down. This pattern can be (A) prior to seeding and (B, C) during the seeding experiment (D) Average shell length ( $\pm 1 \mathrm{SE}$ ) of seeded paua through time. (E) Percentage survival of the original cohort $( \pm 95 \%$ confidence interval) through time

It is difficult to compare growth rates of seed Haliotis iris among sites at Chatham Island because of the varying seasons that the seed were in place. Both Poore (1972c) and Sainsbury $(1982 \mathrm{a}$, b) recorded average annual growth increments of ca 20 to $25 \mathrm{~mm}$ for paua $<20 \mathrm{~mm}$ in length. Pirker (1992) found that annual growth of juveniles fell within this range but that there were significant differences among sites, and between years within a site. At Chatham Island, annualized average growth rates ranged between 13.5 and $24.3 \mathrm{~mm}$. These estimates, however, reflect not only variations among sites but also the different seasons for which paua grew at each site and possibly the effects of differential mortality of smaller seed. Some of the problems of estimating growth rates would be obviated by having all seed of about the same initial size. To reduce the costs of raising seed and achieve greater pre- seen for several years and offers a way to tag hatchery paua cheaply and in large numbers.

Another potential problem with hatchery seed is a restricted genetic stock from using only a few parent animals for spawning. Smith \& Conroy (1992) recommend that seed should originate from at least 5 males and 5 females to retain $95 \%$ genetic variation of the parent stock. The population consequences of reduced genetic variation of seeded abalone in terms of growth, survival, and future breeding are unknown. Because of these uncertainties the parent stock should be as diverse as possible.

In the case of enhancing commercially fished populations, the major reason for attempting enhancement is an economic return. The financial projections from these trials are uncertain because of the relatively short periods for which growth and survival were esti- 
mated at most sites. They were necessary, however, because of the long-term nature of enhancement programmes and the need to have an indication of whether future work is worth pursuing. One site in particular, Port Hutt (Alabama), offers the best chances for a financial return on the initial investment. Other sites may also prove to be financially viable if future recapture rates are high. Some sites, particularly the sandy ones at Owenga and Kaingaroa, are inappropriate for enhancement and have little chance of achieving adequate survival for an economic return.

The major conclusion from this study is that the variability in growth and survival can be reduced by choosing particular habitats and sites for enhancement. Selection of sites is difficult because areas where adults occur do not necessarily have juvenile paua or juvenile habitat. Although several studies have shown that juvenile abalone are found in rock crevices and beneath boulders (Poore 1972c, Shepherd \& Turner 1985, McShane et al. 1990, McShane \& Smith 1991), it is clear from this study that the habitat for seeding must be fairly extensive and away from areas where sand movement can destroy it. Movement of juveniles from cryptic habitats to open reef occurs when paua reach 70 to $90 \mathrm{~mm}$. The process of dispersing to rocky reefs along the coast may take several years (Poore 1972c).

The results imply that 2 strategies may lead to successful enhancement. One is to place seed in relatively small numbers in numerous patches of habitat as they are encountered. This takes more effort in transporting seed paua to many sites, and presents risks in stressing them. However, it spreads the risk of habitatrelated mortality over many different sites. Another strategy is to locate as many larger sites as possible and use these as nurseries for juvenile paua. When these grow to 70 to $90 \mathrm{~mm}$ they can be transplanted to other sites for adult growth. This would take account of the pronounced differences in the habitat requirements of juvenile and adult paua. Juveniles feed on small algae and diatoms and live cryptically, while adults feed on drift and attached algae on open rock surfaces (Tunbridge 1967, Poore 1972a, Garland et al. 1985). The fishery for paua occurs in many places that seem to be far removed from juvenile habitat. By using nursery areas and transplantation, many of these good fishing sites can be replenished without relying on the chance events of natural movement of paua into these areas.
KAINGAROA

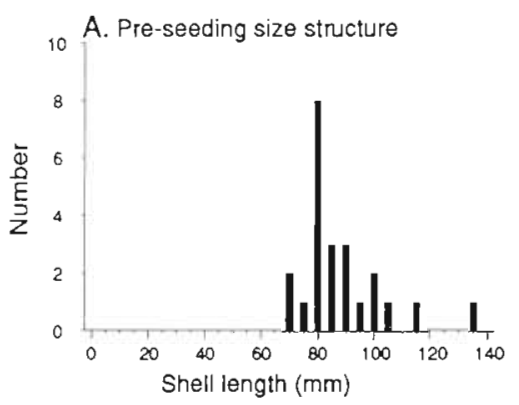

B. Initial seed sizes (27 May 91)
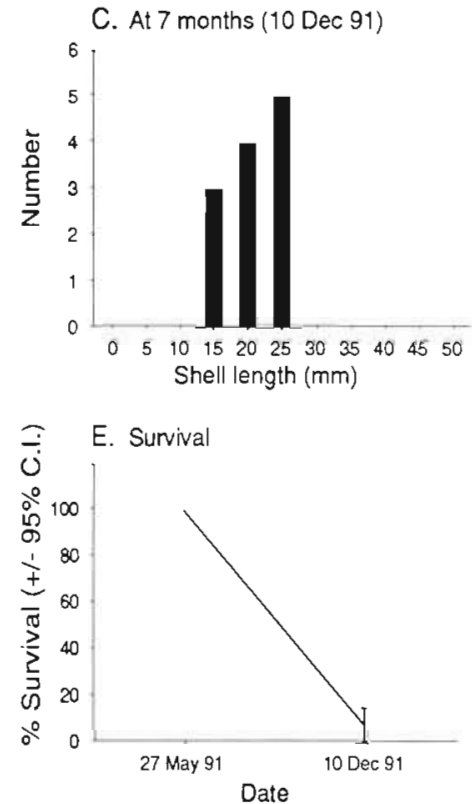

Fig. 9. Haliotis iris. Size-frequencies of abalone at Kaingaroa (A) prior to seeding and (B, C) during the seeding experiment. (D) Average shell ength ( $\pm 1 \mathrm{SE}$ ) of seeded paua through time. (E) Percentage survival of the original cohort ( $\pm 95 \%$ confidence interval) through time

Transplantation of abalone is feasible, but has not been done in New Zealand. A study on Haliotis kamtschatkana in Canada found that relaying stunted individuals to favourable sites resulted in survival estimates similar to the control site but increased growth relative to the control site (Emmett \& Jamieson 1989). This option requires further study in New Zealand and, if viable, may offer the best hope of successfully seeding paua in large numbers to fishing areas.

It seems clear that there is no direct correlation between juvenile and adult numbers among sites, a result found for other species (Shepherd et al. 1992a). Settlement requires particular chemical cues (Morse et al. 1979), larval drift may be associated with topographic features of the coast (McShane et al. 1990), and recruitment is highly variable among sites and years (Sainsbury 1982a, McShane \& Smith 1991). In 
sites where juvenile habitat is abundant, there may be differences in available food (Poore 1972a, b), predation pressure, particularly by mobile reef fishes (Choat \& Ayling 1987), and exposure. The decoupling of numbers in the different life stages of paua means the identification of within-site sources of mortality is essential in understanding the population structure and dynamics of abalone populations. This study has shown that shifts in habitat, especially burial by sand, greatly affects survival of juvenile paua. Therefore, by carefully choosing sites, the risk of mortality due to habitat shifts can be greatly reduced.

The financial returns for abalone are increasingly favourable to seeding of hatchery juveniles. For example, the price of paua meat has increased by over NZ $\$ 30 \mathrm{~kg}^{-1}$ during the past $12 \mathrm{mo}$. The commercial success of seeding will depend largely on the continuation of this trend and the reduction of seed mortality to that of the best sites in this study. It shouid aiso be noted that, as in any wild fishery, enhancement with hatchery-raised juveniles is not a substitute for good fisheries management.

Acknowledgements. I thank the staff of MAF Fisheries and Salmon-Smith-Biolab for use of facilities. I thank Steve Mercer, in particular, for his invaluable field assistance; John Schellevis for helping to set up the contract and Dr John McKoy for his interest and institutional support; Graeme Moss, John Illingworth for hatchery support; and paua fishers Roger and Nicki Beattie, Peter Broad, Barry Lanauze, Andy Hough, John Bates, and Eddie Reriti. Thanks to J. van Berkel for graphics, Drs P. Breen, P. McShane, L. Tong, M. Foster, J. Pearse, and an anonymous referee for helpful criticism.

\section{LITERATURE CITED}

Breen, P. A. (1992). A review of models used for stock assessment in abalone fisheries. In: Shepherd, S. A., Tegner, M. J., Guzman del Proo, S. A. (eds.) Abalone of the world; biology, fisheries and culture. Blackwells, Oxford, p. $253-275$

Choat, J. H., Ayling, A. M. (1987). The relationship between habitat structure and fish faunas on New Zealand reefs. J. exp. mar. Biol. Ecol. 110: 257-284

Connell, J. J. (1985). The consequences of variation in initial settlement vs. post-settlement mortality in rocky intertidal communities. J. exp. mar. Biol. Ecol. 93: 11-45

Emmett, B., Jamieson, G. S. (1989). An experimental transplant of prerecruit abalone in Barkley Sound, British Columbia. Fish. Bull. U.S. 87: 95-104

Garland, C. D., Cooke, S. L., McMeekin, T A. (1985). Ingestion of the bacteria on the cuticle of crustose (nonarticulated) coralline algae by post-larval and juvenile abalone (Haliotis ruber Leach) from Tasmanian waters. J. exp. mar. Biol. Ecol. 91: 137-149

Harrison, A. J. (1986). Gastropod fisheries of the Pacific with particular reference to Australian abalone. Can. Spec. Publ. Fish. Aquat. Sci. 92: 14-22

Ino, T. (1966). The abalone science and its propagation in
Japan. Nippon Suisan Shigen Hogo Kyokai, Suisan Zoyoshoku Soshu 11.1-104 (translated from Japanese by Trans. Ser. Fish. Res. Bd Can. 1078, 1968)

Jones, G. P. (1990). The importance of recruitment to the dynamics of a coral reef fish population. Ecology 71 : $1691-1695$

Keough, M. J. (1988). Benthic populations: is recruitment limiting or just fashionable? Proc. 6th int. coral Reef Symp 1. $141-148$

McShane, P. (1991). Density-dependent mortality of recruits of the abalone Haliotis rubra (Mollusca: Gastropoda). Mar. Biol. 110: 385-389

McShane, P, Black, K. P., Smith, M. G. (1990). Recruitment processes in Haliotis rubra (Mollusca: Gastropoda) and regional hydrodynamics in south-eastern Australia imply localised dispersal of larvae. J. exp. mar. Biol. Ecol. 124: $175-203$

McShane, P., Smith, M. G. (1991). Recruitment variation in sympatric populations of Haliotis rubra Leach (Gastropoda: Haliotidae). Mar. Ecol. Prog. Ser. 73: 203-210

Morse, D. E., Hooker, N., Duncan, H., Jensen, L. (1979). Gamma-aminobutyric acid, a neurotransmitter, induces planktonic abalone larvae to settle and begin metamorphosis. Science 204: 407

Newman, G. G. (1966). Movements of the South African abalone Haliotis midae. Investl Rep. Div. Sea Fish. S. Afr. 56: $1-19$

Pirker, J. G. (1992). Growth, shell-ring deposition, and mortality of paua (Haliotis iris Martyn) in the Kaikoura region. M.Sc. thesis, University of Canterbury, Christchurch

Poore, G. C. B. (1972a). Ecology of New Zealand abalones, Haliotis species (Mollusca: Gastropoda) 1. Feeding. N.Z. J. mar. Freshwat. Res. 6: 11-22

Poore, G. C. B. (1972b). Ecology of New Zealand abalones, Haliotis species (Mollusca: Gastropoda) 2. Seasonal and diurnal movement. N.Z. J. mar. Freshwat. Res. 6: 246-258

Poore, G. C. B. (1972c). Ecology of New Zealand abalones, Haliotis species (Mollusca: Gastropoda) 3. Growth. N.Z. J. mar. Freshwat. Res. 6: 534-559

Sainsbury, K. J. (1982a). Population dynamics and fishery management of the paua, Haliotis iris. I. Population structure, growth, reproduction, and mortality. N.Z. J. mar. Freshwat. Res. 16: 147-161

Sainsbury, K. J. (1982b). Population dynamics and fishery management of the paua, Haliotis iris. Il. Dynamics and management as examined using a size class model. N.Z. J. mar. Freshwat. Res. 16: 163-173

Saito, K. (1979). Studies on propagation of Ezo abalone, Haliotis discus hannai Ino. I. Analysis of the relationship between transplantation and catch. Bull. Jap. Soc. Sci. Fish. 45: 695-704

Saito, K. (1984). Ocean ranching of abalones and scallops in northern Japan. Aquaculture 39: 361-373

Schiel, D. R. (1989). Species enhancement in the natural environment. Proceedings of AQLANZ'88 conference in Wellington, N.Z. (available from MAF Fisheries, PO Box 297, Wellington, New Zealand)

Schiel, D. R. (1992a). The enhancement of paua (abalone) populations in New Zealand. In: Shepherd, S. A., Tegner, M. J., Guzman del Proo, S. A. (eds.) Abalone of the world; biology, fisheries and culture. Blackwells, Oxford, p. $474-484$

Schiel, D. R. (1992b). The paua (abalone) fishery of New Zealand. In: Shepherd, S. A., Tegner, M. J., Guzman del Proo, S. A. (eds.) Abalone of the world; biology, fisheries and culture. Blackwells. Oxford, p. 427-437 
Schiel, D. R., Breen, P. A. (1991). Population structure, ageing and fishing mortality of the New Zealand abalone Haliotis iris. Fish. Bull. U.S. 89: 681-691

Schiel, D. R., Welden, B. A. (1987). Responses to predators of cultured and wild red abalone, Haliotis rufescens, in laboratory experiments. Aquaculture 60: 173-188

Shepherd, S. A. (1986). Movement of the Southern Australian abalone Haliotis laevigata in relation to crevice abundance. Aust. J. Ecol. 11: 295-302

Shepherd, S. A. (1987). Aspects of the biology of the abalone Haliotis laevigata and Haliotis scalaris. Ph.D. thesis Deakin University

Shepherd, S. A., Breen, P. A. (1992). Mortality in abalone: its estimation, variability and causes. In: Shepherd, S. A., Tegner, M. J., Guzman del Proo, S. A. (eds.) Abalone of the world i biology, fisheries and culture. Blackwell, Oxford p. $276-304$

Shepherd, S. A., Lowe, D., Partington, D. (1992a). Studies on southern Australian abalone (genus Haliotis) XIII: larval dispersal and recruitment. J. exp. mar. Biol. Ecol. 164: $247-260$

Shepherd, S. A., Tegner, M. J., Guzman del Proo, S. A. (eds.) (1992b). Abalone of the world biology, fisheries and culture. Blackwell, Oxford

Shepherd, S. A., Turner, J. A. (1985). Studies on southern Australian abalone (genus Haliotis). VI. Habitat preference and abundance and predators of juveniles. J. exp mar. Biol. Ecol. 93: 285-298

This article was submitted to the editor
Smith, P. J., Conroy, A. M. (1992). Loss of genetic variation in hatchery produced abalone, Haliotis iris. N.Z. J. mar. Freshwat. Res. 26: 81-85

Tegner, M. J., Butler, R. A. (1985). The survival and mortality of seeded and native red abalones, Haliotis rufescens, on the Palos Verdes Peninsula. Calif. Fish Game 71 150-163

Tegner, M. J., Butler, R. A. (1989). Abalone seeding. In: Hahn K. O. (ed.) Handbook of culture of abalone and other marine gastropods. CRC Press, Boca Raton, p. 157-182

Thayer, G. W. (ed.) (1992). Restoring the nation's marine environment. Maryland Sea Grant College, University of Maryland, College Park,

Tong, L. J., Moss, C. A. (1992). The New Zealand culture system for abalone. In: Shepherd, S. A., Tegner, M. J., Guzman del Proo, S. A. (eds.) Abalone of the world; biology, fisheries and culture. Blackwells, Oxford, p. 583-591

Tunbridge, B. R. (1967). Feeding habits of paua (Haliotis iris Martyn). Fish. tech. Rep. N.Z. mar. Dep. 20: 1-18

Underwood, A. J., Denley, E. J. (1984). Paradigms, explanations and generalizations in models for the structure of intertidal communities on rocky shores. In: Strong, D. Simberloff, D., Abele, L. G., Thistle, A. B. (eds.) Ecological communities: conceptual issues and the evidence Princeton University Press, Princeton, p. 151-180

Whang, H. C., Chung, K. O. (1977). Study on relationship between exposure time and mortality of young abalone, Haliotis discus (Reeve). Bull. Fish. Res. Devel. Agency, Busan 18: 123-129

Manuscript first received: November 9, 1992

Revised version accepted: May 10,1993 